\title{
Uber die Bildung von Lysosomen im fetalen Dünndarm
}

Bei der Bildung der primären Lysosomen sollen nach den gegenwärtigen Anschauungen Golgi-Apparat und endoplasmatisches Reticulum führend sein 1,2. Offenbar kann die Lysosomenbildung in fetalen Dünndarmepithelzellen der Ratte vom 17,-18. Schwangerschaftstag auch vom Plasmalemm ausgehen. Wir beobachteten im basalen Zytoplasma dieser Zellen zahlreiche runde, ovale bzw. polymorphe, von einer Membran umgebene, saure phosphatase-positive Granula von 1500-3000 Å Durchmesser, die wir für Lysosomen halten.

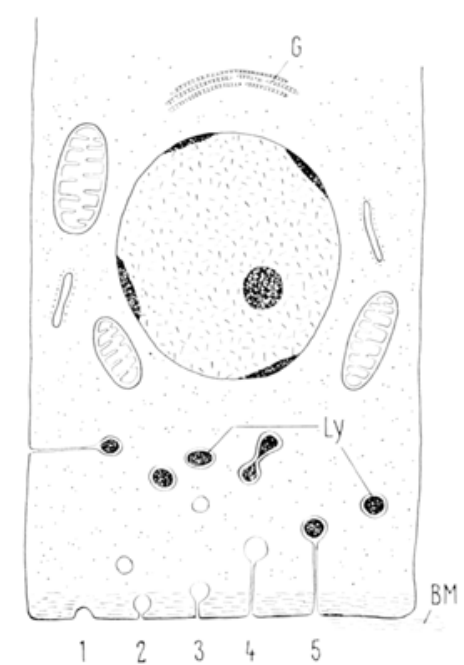

Schematische Darstellung einer Dünndarmepithelzelle der Ratte vom 17. Embryonaltag. 1-5 Plasmalemminvaginationen, die als Vorstufen primärer Lysosomen (Ly) gedeutet werden. BM, Basalmembran; G, Golgi-Apparat.

\section{Phagocytosis of Zymosan Particles by Mast Cells}

Despite the voluminous work that has appeared dealing with the mast cell ${ }^{1-4}$, the physiologic functions of this cell are still poorly understood. Although mast cells are thought not to be phagocytic, some suggestive but inconclusive evidence has appeared to indicate otherwise. Dougherty and SchNeEBELI ${ }^{\mathbf{5}, 6}$ have recorded, by timelapse cinematography, the in vitro behavior of mouse mast cells exposed to glucan particles. They concluded that some mast cells attempted to engulf the glucan. However, this resulted only in surface indentation, and lysis of the mast cells followed before ingestion occurred. RoBERTs?, by the use of autoradiography, described the incorporation of a tritiated soluble sulfanylazo derivative of porcine $\gamma$-globulin and noted a decreased basophilia of the cytoplasmic granules of the labeled mast cells. This was attributed to binding of the antigen to the granules which prevented subsequent binding of the dye.

In the course of studies on chemotaxis ${ }^{8}$, it was noted that zymosan injected i.p. into rats appeared to become embedded in mast cells. It was not possible by the techniques used to establish with certainty whether the particles were intracellular or were merely indenting the mast cell surface. Therefore, electron microscopic techniques were used to re-examine this finding.
In unserem Untersuchungsmaterial haben wir keine Hinweise dafür gefunden, dass diese ausschliesslich im basalen Zytoplasma vorkommenden Lysosomen im supranucleär gelegenen Golgi-Apparat oder - wie vermutet wurde $^{3}$ - im endoplasmatischen Reticulum entstehen. Wir nehmen stattdessen an (Figur), dass sie sich aus bläschenförmigen Einsenkungen und Abschnürungen des basalen und seitlichen Plasmalemms entwickeln, die wir häufig in unmittelbarer Nähe der Lysosomenanhäufungen beobachten. Für diese Annahme spricht, dass die Abschnürungen etwa denselben Durchmesser wie die Lysosomen besitzen und dass einige Vesikel, die durch einen etwa 4000 bis $5000 \AA$ langen Plasmalemmstiel mit der Zellmembran in Verbindung stehen, bereits vor ihrer Ablösung von der Zellwand elektronendichtes, osmiophiles Material in ihrem Zentrum enthaiten. Weitere Untersuchungen müssen zeigen, ob diese Art der Lysosomenbildung auch für andere embryonalen Gewebe zutrifft 4 .

Summary. Electron microscopical and enzyme histochemical investigations suggest that in the fetal small intestine of the rat primary lysosomes originate from invaginations of the cell membrane and not from the Golgi-apparatus or the endoplasmic reticulum.

\section{VOLLRATH}

Anatomisches Institut der Universität, 87 Wïrburg (Deutschland), 27. November 1967.

1 C. De Duve und R. Wattiaux, A. Rev. Physiol, 28, 435 (1966).

2 P. B. Gahan, Int. Rev. Cytol. 21, 1 (1967).

3 A. F. Hayward, J. Anat. 101, 615 (1967).

4 Mit Unterstützung durch dic Deutsche Forschungsgemeinschaft.
Male rats of the Sprague-Dawley Holtzman strain, 35-61 days old, were injected i.p. with $0.1 \mathrm{ml}$ of a zymosan preparation (Standard Brands Inc., New York, N.Y., Lot $\mathrm{OB}-298$ ) suspended in $0.9 \% \mathrm{NaCl}$ solution. After various time intervals, rats were decapitated and peritoneal fluid was harvested for both light and electron microscope studies. Smears were stained with WrightGiemsa. In addition, wet mounts of both living and dead cells, with and without staining, were also examined. For

' J. F. RILEY, The Mast Cells (E. and D. Livingstone Ltd., Edinburgh and London 1959).

${ }^{2}$ M. A. Kelsall and E. D. CRABB, Lymphocytes and Mast Cells (The Williams and Wilkins Co., Baltimore, Md. 1959).

3 J. P'ADAwER, ed. Ann, N.Y. Acad. Sci. 103, 1 (1963).

4 H. Selye, The Mast Cells (Butterworth Inc., Washington, D.C. 1965).

5 T. F. Dougherty and G. L. Schneebeli, J. Reticuloendothelial Soc. 2, $361(1965)$.

${ }^{6}$ T. F. Dongherty and G. L. Schneebel, Proc. VIII Int. Congr. Anat., Wiesbaden (Thieme Verlag, Stuttgart 1965), p. 32.

'A. N. Roberts, Am. J. Path. 49, 889 (1966).

${ }^{8}$ G. J. Fruhman, Ann. N.Y. Acad. Sci. 113, 968 (1964). 